\title{
DE INSTITUIÇÃO PSIQUIÁTRICA A CEMITÉRIO: PERSCRUTANDO A FUNDAÇÃO E TRANSFORMAÇÃO DO ABRIGO MUNICIPAL DE ALIENADOS OSCAR SCHNEIDER
}

FROM A PSYCHIATRIC INSTITUTION TO A GRAVEYARD: EXAMINING THE FOUNDATION AND TRANSFORMATION OF THE "ABRIGO MUNICIPAL DE ALIENADOS OSCAR SCHNEIDER"1 DE UNA INSTITUCIÓN PSIQUIÁTRICA A UN CEMENTERIO: EXAMINANDO LA FUNDACIÓN Y TRANSFORMACIÓN DEL "ABRIGO MUNICIPAL DE ALIENADOS OSCAR SCHNEIDER"

\section{Mariana Zabot Pasqualotto* Andréa Vieira Zanella*}

\begin{abstract}
RESUMO
Neste artigo, busca-se relatar a experiência de uma pesquisa que se debruçou sobre as memórias invisibilizadas de um cemitério da cidade de Joinville, Estado de Santa Catarina, cuja história de seu território está ligada à existência, no passado, de duas instituiçóes de confinamento de sujeitos infames: um Abrigo de Alienados (1923-1942) e um Presídio Político (19421945). A escuta dos personagens que narram suas experiências com esse local e as estratégias do flâneur como forma de deixar-se levar na busca pelas memórias por aquilo em que se configuram sentidos foram os fundamentos do exercício de "ficcionar" sobre esse determinado objeto de estudo, a partir de uma relação sensível com esse campo, uma "Cidade dos Mortos", onde foi possível escutar as vozes que nele ainda pulsam e tensionam a história desse local e seu aparente estado de silêncio na cidade.
\end{abstract}

Palavras-chave: Memória. Cidade. Infâmia.

\section{ABSTRACT}

The present article aims to report the experience resulting from a research focused on the unveiled memories of a cemetery in the city of Joinville, Santa Catarina State (SC), in Brazil. The history about the cemetery tract of land is connected to the existence, in the past, of two institutions for the confinement of infamous subjects: A Lunatic Asylum (1923-1942) and a Prison for Politicians (1942-1945). Listening to the characters narrating

\footnotetext{
${ }^{1}$ Oscar Schneider Municipal Lunatic Asylum.

Texto recebido em 12 de fevereiro de 2017 e aprovado para publicação em 16 de fevereiro de 2018.

"Doutora em Psicologia pela Universidade Federal de Santa Catarina (UFSC). E-mail: mariana.zabot@gmail.com. Telefone: (48) 9817-6748.

"Professora titular no Programa de Pós-Graduação em Psicologia na UFSC. E-mail: avzanella@gmail.com. Telefone: (48) 99818670. Endereço: Universidade Federal de Santa Catarina - Centro de Filosofia e Ciências Humanas - Programa de PósGraduação em Psicologia - Campus Universitário - Trindade, Caixa Postal 476, Florianópolis-SC, Brasil. CEP: 88040-900.
} 
their experiences linked to this place, and the flâneur's strategies as a manner to allow oneself to be carried away when searching for the memories by what the senses are made up, were the fundamentals of the exercise of "fictionalizing" about this certain object of study, starting from a sensitive relation with this field, a "City of the Dead", where it was possible to listen to the voices that still pulse in it and tension the history of this place and its apparent state of silence within the city.

Keywords: Memory. City. Infamy.

\section{RESUMEN}

En este artículo se relata una experiencia de investigación que se orientó hacia las memorias invisibilizadas de un cementerio en la ciudad de Joinville (Santa Catarina, Brasil). La historia de ese territorio está ligada a la existencia, en el pasado, de dos instituciones de confinamiento de sujetos infames: un Abrigo para Alienados (1923-1942) y un Presidio Político (1942-1945). Escuchar los personajes que narran sus experiencias relacionadas con ese lugar, y las estrategias del flaneur como forma de dejarse llevar en busca de memorias que configuran sentidos, fueron los fundamentos del ejercicio de creación sobre el objeto de estudio, a partir de una relación sensible con ese campo, una "Ciudad de muertos", donde fue posible escuchar las voces que todavía pulsan y tensionan la historia del lugar y su aparente estado de silencio en la ciudad.

Palabras clave: Memoria. Ciudad. Infamia.

\section{O CEMITÉRIO COMO ESPAÇO DE MEMÓRIAS: SOBRE A EXPERIÊNCIA DE PESQUISA NA “CIDADE DOS MORTOS”}

$\mathrm{N}$

este artigo, busca-se relatar a experiência de uma pesquisa que se debruçou sobre as memórias de um determinado território da cidade, um cemitério. Conjecturando os vestígios de sua história pretérita em confronto com o presente e sua paisagem atual no contemporâneo da cidade, tem-se como objetivo, neste trabalho, refletir sobre as possibilidades de se fazer pesquisa nesse território, campo simbólico onde se depositam algumas memórias de uma determinada sociedade. A pesquisa perscrutou os rastros deixados de épocas passadas assim como problematizou essa experiência de pesquisa como forma de ficcionar sobre esse determinado objeto de estudo, ao deixar-se afetar, como um flâneur, às memórias e sentidos presentes em um cemitério.

A escolha da pesquisa por determinado cemitério se justifica pela sucessão de acontecimentos que ligam esse território à morte, não apenas em seu 
estado mais concreto. Além do luto social que se atribui a todo cemitério, ou seja, do luto sobre a falência dos corpos, sobre tal cemitério se tensiona o luto social que permanece invisibilizado a respeito da existência, no passado desse terreno, de uma edificação onde funcionaram, em tempos diferentes, duas instituições de clausura que recebiam "mortos-vivos", sujeitos que experimentaram suas mortes em vida, ao serem produzidos como infames ${ }^{2}$ em uma determinada época.

Trata-se do Cemitério Municipal de Joinville, Estado de Santa Catarina, Brasil, cuja história é composta por cenários que dizem respeito a tempos diferentes: nos fundos do cemitério, fundado em 1913, edifica-se a primeira instituição psiquiátrica da cidade, o Abrigo Municipal de Alienados Oscar Schneider, que funcionou entre os anos de 1923 a 1942. Após o fechamento dessa instituição, o prédio serviu à mesma finalidade de isolamento, porém de outra categoria de indivíduos, os presos políticos, constituindo-se como Presídio Político Oscar Schneider (1942 a 1945). Depois da desativação deste último, o prédio ainda resistiu por alguns anos (servindo como moradia a famílias de policiais militares), sendo, mais tarde, demolido para a ampliação do cemitério. Este, então, constitui seu cenário último, composto por túmulos e jazigos, e o apagamento de existências.

Os percursos iniciais da pesquisa possibilitaram deparar-se com uma memória que se mostrou confusa ou pouco evidente sobre a existência desse prédio, em diferentes espaços da cidade instituídos como locais de salvaguarda de histórias a serem lembradas, como o Arquivo Histórico, a Casa da Memória, a Biblioteca Municipal, os museus, entre outros. Também se constatou o desconhecimento da população sobre a existência de ambas as instituições. Aqueles que sabem sobre suas histórias são alguns poucos cidadãos antigos na cidade, o que também demonstra que essa memória não sobreviveu potencialmente ao longo dos tempos.

Embora a existência desse lugar tenha sido apagada no ato de sua demolição e silenciada nas narrativas que circulam pela cidade, aposta-se que, assim como a imagem de um palimpsesto (pergaminho em que um texto primitivo teria sido raspado para dar lugar a outro), os restos de sua existência nos indicam a "memória viva de um passado morto" (Santos, 2006). As histórias que envolvem a criação e o funcionamento do prédio continuam grafadas nesse espaço, constituindo-o como um campo de tensão entre diferentes tempos.

\footnotetext{
${ }^{2}$ Utiliza-se o conceito de infâmia, neste artigo, com base no texto A vida dos homens infames, de Foucault, no qual o autor trabalha com os rastros de existências (presentes nos arquivos do internamento, da polícia, das petições ao rei e das cartas régias com ordem de prisão, que datam de 1660-1760) de pessoas que tiveram suas vidas obscurecidas pelo poder, mas que, ao mesmo tempo, também pelo choque com o poder, fizeram-se perdurar nas poucas linhas dos documentos que descrevem sua existência (Foucault, 2007).
} 
Para Hissa e Melo (2008, p. 297), “A história é história sobre história, escrita sobre escrita, espaço sobre espaço". Isso nos inspira a fazer a leitura da paisagem que constitui o cemitério: embora possa parecer uma paisagem "congelada" por abrigar a morte e o silêncio, participa da "história viva" da cidade, como nos diz Santos (2006). Para o autor:

De fato, a paisagem permite apenas supor um passado. Se queremos interpretar cada etapa da evolução social, cumpre-nos retomar a história que esses fragmentos de diferentes idades representam juntamente com a história tal como a sociedade a escreveu de momento em momento. Assim, reconstituímos a história pretérita da paisagem, mas a função da paisagem atual nos será dada por sua confrontação com a sociedade atual (Santos, 2006, p. 69).

Nesse sentido, buscou-se na pesquisa realizada sobre esse território da cidade os vestígios e vozes a testemunhar um passado que ainda confronta o presente e produz possibilidades de compor sentidos outros à sua realidade, inscrevendo memórias futuras. Tensionando esses diferentes tempos, entendemos o cemitério a partir da noção de "espaço", que "testemunha a realização da história, sendo, a um só tempo, passado, presente e futuro" (Santos, 2006, p. 102).

Essas noções conduzem a maneira como a história desse território é entendida na pesquisa. Antes de fazer dialogar diferentes vozes e tensionar os tempos que a esse espaço se relacionam, passa-se inicialmente a refletir sobre algumas questóes que alçaram, na pesquisa, o cemitério à condição de campo simbólico para se pensar a questão da produção social da memória, daquilo que se quer perdurar no tempo, e os silenciamentos/esquecimentos a que são relegados acontecimentos, existências.

\section{O CEMITÉRIO COMO CAMPO SIMBÓLICO DA MEMÓRIA}

Junto à expressão "necrópole", "cidade dos mortos", em Silva (2000), temos que outras expressões, tais como "território do descanso eterno" e "campo santo", enviesadas pelocaráter religioso, passaram a comporossignificados que se atribuíam à palavra cemitério, que primitivamente queria dizer o "lugar onde se dormia" O termo "necrópole" a significar uma "cidade de mortos" indica que o espaço que constitui um cemitério é marcado pela presença de mais de uma sepultura (Castro Filho, 2007) e, além disso, podemos pensar que, ao ser cunhado como "cidade", o cemitério parece ser reconhecido como um espaço onde se constituem relaçôes específicas, estas estabelecidas a partir do contato com os vivos, que atribuem a esse lugar certos valores, estabelecem seus cultos, ritos e ali depositam algumas de suas memórias.

\footnotetext{
${ }^{3}$ Proveniente da palavra grega kaimão (dormir) (Silva, 2000).
} 
Assim, o cemitério não se constitui meramente como destino final que damos aos corpos, mas como um lugar de memória, de onde ainda se podem extrair as vozes dos ausentes; lugar de "rastros", que revela a "presença de uma ausência" e a "ausência de uma presença" (Gagnebin, 2006); na ausência da materialidade dos corpos, os rastros que ali se inscrevem presentificam a ausência, enquanto fazem lembrar o que não está mais presente.

As lápides e os túmulos são assim símbolos da tentativa de luta contra o esquecimento dos mortos. Se recorrermos à palavra grega sema, discutida por Gagnebin (2006), vemos que ela comporta um duplo significado: do seu significado original de "túmulo", a palavra, posteriormente, passou a significar também "signo", o que nos faz considerar o túmulo como "signo dos mortos". $\mathrm{O}$ fato de termos as inscriçôes funerárias entre os primeiros rastros de signos escritos da história da humanidade demonstra a forma como memória, escrita e morte amalgamam-se num só processo. Túmulo, signo, palavra e escrita lutam, todos eles, contra o esquecimento (Gagnebin, 2006).

Passamos a considerar, assim, o cemitério como um campo simbólico de luto social, onde se erigem lápides às pessoas de todas as camadas sociais; àquelas que pertencem à história oficial da cidade e mesmo as infames. Todas fazem parte de um rito de luto e têm o direito de serem memoradas nesse lugar.

Emprestamos ainda a seguinte reflexão de Benjamin (2012) para pensar sobre tal simbologia que esse espaço carrega:

Pois não somos tocados por um sopro do ar que envolveu nossos antepassados? Não existem, nas vozes a que agora damos ouvidos, ecos das vozes que emudeceram? [. . .]. Se assim é, então existe um encontro secreto marcado entre as geraçóes precedentes e a nossa. Então, alguém na terra esteve à nossa espera (p. 242).

Esse "encontro secreto marcado entre as gerações" sobre o qual nos fala Benjamin, que pode ser considerado como o encontro dos vivos com os mortos, faz-nos pensar no modo como os habitantes da pólis estão enredados, no presente, ao sopro das vozes que podem ser ouvidas do passado, e que assim projetam futuros, e ainda, se esse encontro é secreto e se faz na presença de vozes emudecidas, o autor nos aponta para a existência de tensionamentos entre passado e presente.

Essa reflexão relaciona-se ao campo do cemitério ao pensar que o encontro entre as gerações ocorre nesse território de maneira exemplar: "Os restos de cultura e de épocas passadas encontram-se nas ruínas, tal como os das gerações passadas, nas sepulturas" (Assmann, 2011, p. 63). 
Considerando-se, então, que os cemitérios comportam muitos símbolos e se concretizam como espaços políticos de luto social, onde todos devem ter o direito de serem memorados, questiona-se: como promover o encontro com os "mortos-vivos", com as vidas infames que se alocaram nesse território? De que forma abordar a história enterrada da existência das instituiçóes da clausura desse espaço? Passamos, agora, a seguir alguns vestígios para confrontar esse passado com o presente.

\section{VESTÍGIOS DA “CIDADE DOS MORTOS”}

O capítulo inicial da história desse terreno se dá por sua escolha para sediar, em 1913, o primeiro cemitério municipal de Joinville. Nos primórdios de sua criação, a região escolhida para abrigá-lo constituía-se num território afastado do centro urbano, distante do contato com os vivos. A seus fundos, dez anos mais tarde, destinou-se a construção do prédio para tratar os chamados loucos da cidade e região.

A transformação e destinação desse espaço à morte (do terreno, aos fundos de um cemitério, em que se edifica um abrigo de alienados, que depois serve como presídio político e, por último, depois de ser moradia para famílias dos policiais militares, recebe os túmulos da ampliação do cemitério) não parece ser mera coincidência, mas, antes, seguir uma trama de acontecimentos que articula a morte, marcadamente presente desde o início da história da cidade, como sua personagem central.

A fundação desse cemitério se deu num contexto do século XIX, marcado pelo "apego" à morte", expressão que Guedes (2005) usa para se referir à preocupação marcadamente presente com a "salvação da alma e a vida eterna", em compasso à crescente mortalidade da colônia, que precedeu o Município de Joinville, onde não se ofereciam condiçôes sanitárias adequadas, dispunha-se de uma medicina rudimentar e era constante a existência de inúmeras epidemias.

Com base nos costumes dos imigrantes que chegavam à colônia, arquitetou-se o primeiro espaço oficial, anterior mesmo ao Cemitério Municipal, o "Cemitério dos Imigrantes", onde eram sepultados os corpos dos imigrantes alemães e italianos, em sua maioria luteranos ${ }^{4}$. Nesse contexto, com a intenção de oferecer um espaço para sepultamento das pessoas de diferentes etnias e tradições religiosas, criou-se o "Cemitério Municipal de Joinville", o primeiro espaço para serem enterrados os mortos administrado pelo Poder Público Municipal. Com a criação do espaço oficial, passou-se a

\footnotetext{
${ }^{4}$ A cidade contava, além do "Cemitério dos Imigrantes", com mais sete cemitérios não oficiais que surgiram próximos a igrejas, ou de casas de famílias que tinham por costume sepultar seus entes em seus próprios terrenos (Guedes, 2005).
} 
proibir os sepultamentos nos demais cemitérios não oficiais, com exceção aos associados da "Comunidade Evangélica Luterana”, que congregava a maioria dos imigrantes de origem germânica (Fochi, 2011).

Importante ressaltar que os terrenos onde os cemitérios oficiais (o Cemitério dos Imigrantes e o Cemitério Municipal) se fundaram na cidade não eram escolhidos por acaso. Eram estabelecidos numa costura dos territórios guiada pelos ideais de urbanização da época e às orientações europeias de sepultamento. Como se acreditava que as exalações provindas dos cadáveres em contato com locais de habitação aumentariam o risco de aparecimento de doenças, construíamse cemitérios em locais altos e afastados da urbe (Guedes, 2005).

Nesse período, no cenário brasileiro, e assim também em Joinville, faziase urgente seguir estratégias sanitárias e educativas para gerir a urbe e seus habitantes. De acordo com Guedes (2005), ao propósito de modernizar a cidade correspondiam estratégias de sanear, limpar e erradicar epidemias, além de transformar a vida privada em pública, fazendo dos cidadãos fiscais de si e dos demais.

A necessidade de urbanização da pólis e de civilização de seus habitantes, princípios que regiam o governo da população naquela época, demonstrou a preocupação da cidade em gerir vivos e mortos; fiscalizavam-se seus cidadãos assim como padronizava-se o sepultamento dos entes falecidos.

Para Fontoura (2005), os problemas vinculados à saúde e higiene que preocuparam a população desde os primórdios da cidade foram objeto dos discursos locais, principalmente no início do século XX, a partir da urbanização provocada pela economia de erva-mate, que movimentava a região e fazia com que Joinville criasse "feições urbanas".

Ainda nesse período, houve a criação de uma "sociedade de embelezamento", que não só se preocupava quanto à "beleza do cenário urbano" como também ditava as normas do convívio em sociedade, mediante a criação de "códigos de posturas". Para Fontoura (2005), é por meio de tais medidas e discursos produzidos sobre a arquitetura e o espaço, como também sobre o comportamento e as relaçóes de convívio de determinados grupos, que se iniciou o projeto de "modernização-urbanização" de Joinville, que passava a se preocupar com a saúde física, moral e intelectual da população.

Entendendo a tessitura da urbe nesse contexto, faz-se importante questionar de que maneira isso passa a incidir sobre os corpos que nela habitavam. Entendendo o corpo como "superfície de inscrição dos acontecimentos" e "inteiramente marcado de história", como nos diz Foucault (2003), passamos 
a imbricar "cidade" e "corpo" numa discussão só; falar das transformações e o processo de urbanização da cidade é também tratar das relaçôes produzidas sobre os corpos que nela habitam.

Como nos propõem Hissa e Nogueira (2013), a vida urbana é constituída das relações "corpo-cidade". Seguindo a compreensão sobre a cidade como um grande corpo urbano, baseado nesses autores, passamos a tomá-la como um espaço de tensionamentos vários, produzidos no confronto de diferentes corpos, e, entre estes, temos aqueles considerados "ordinários", corpos que se movimentam entre as "fissuras do planejado e do disciplinado" (Hissa \& Nogueira, 2013).

Assim, questionamos de que maneiras se inscreviam, nos primórdios civilizatórios de uma cidade, as práticas sociais sob os corpos e o espaço da urbe. Quais os conflitos que emergiam da pluralidade de corpos a compor a vida urbana? Empenhada em se construir aos moldes de práticas higienizadoras e disciplinares, podemos pensar que tais ações tomadas pelos que governavam a urbe incidiam sobre os citadinos e esquadrinhavam seu espaço, deixando marcas sobre o "corpo da cidade" e os "corpos na cidade".

No período de urbanização e modernização da cidade de Joinville, podemos pensar que corpos e lugares passaram a ser concebidos como ordinários; e os ditos loucos participaram desse processo contínuo, em que a cada época, sujeitos diferentes são eleitos a representar a insignificância da vida citadina. A loucura, representativamente (in)significante nessas condiçôes históricas, por desafiar a sociedade centrada na razão, faz surgir modos de pensar que a produzem como desviante, fora da norma; como nos demonstra Foucault, em a História da loucura.

Por serem criaturas ordinárias a resistir a certas lógicas dos poderes e ao cerceamento de modos de habitar a cidade, aos ditos loucos da cidade de Joinville sempre se destinou, na costura que se fez dos seus territórios, os lugares mais obscuros para se habitar. Confinava-se o que se queria distante do contato humano, dos vivos, assim como a morte.

Anterior à construção da primeira instituição psiquiátrica do Município, o Abrigo Municipal de Alienados Oscar Schneider, os "loucos indigentes" eram recolhidos num quartel da cidade, em condições precárias, como se relata no seguinte documento:

Tendo-se por falta de outro lugar, recolhido até agora, no quartel, os doidos indigentes e levando em consideração que estes pobres infelizes tinham de supportar ${ }^{5}$ as infecções e o mau trato de uns quartos insalubres e sem luz, consegui, [. . .] uma verba destinada à manutenção daqqueles pobres desgraçados, [. . .] havendo-se a Camara

${ }^{5} \mathrm{Na}$ transcrição dos documentos preservou-se a grafia vigente à época em que foram redigidas. 
comprometido a recolher em edifício mais apropriado os seis alienados existentes (Joinville, 1906, p. 6, grifo nosso).

Tal "edifício mais apropriado" se tratava do prédio que abrigou o extinto hospital da cidade, chamado "Hospital da Direção da Colônia Dona Francisca", que tinha por função o acolhimento aos "desvalidos", como na época referiam-se às pessoas de baixo poder aquisitivo, idosas ou "incapazes" de cuidado próprio (Guedes, 1996). No entanto o hospital que alegava não ter condições de tratar os chamados "doentes mentais" lhes conferia cuidado

Somente em casos excepcionais e só por curto espaço de tempo, quanto preciso for para que as respectivas famílias ou curadoras organizem em seus domicílios um lugar próprio e seguro para a conservação destes infelizes, mas nunca excedendo o prazo de 3 dias (Joinville, 1898 , p. 8).

O prédio onde funcionava o hospital já tinha suas estruturas frágeis e, sem condiçóes de atender adequadamente a população, mudou-se, em 1906, para um novo endereço. Construído em terreno doado por um padre na cidade, sob a condição de ser administrado pelas irmãs de caridade, o território do hospital configurou-se como um "campo santo" na cidade (Guedes, 1996).

Campo santo o qual aos loucos não se permitiu adentrar. A eles destinou-se o antigo prédio, que passou a ser chamado de "Hospício de Alienados", lugar onde os que ali eram deixados continuavam a ser mantidos em condições insalubres e sem qualquer tratamento médico ou psiquiátrico. Era o depósito das vidas infames, que, em contraste com o campo santo do hospital, constituía um espaço ordinário na cidade.

No trecho de um relatório, apresentado em uma revista de circulação à época, faz-se crítica ao estado dos sujeitos mantidos nos depósitos da loucura da cidade:

Tenho a informar ao Conselho que o serviço de assistência prestado nesta cidade aos loucos é o mais incompleto e o mais lastimável que se pode imaginar. São recolhidos entre 16 e 20 pessoas em um edifício pequeno e sem condições hygienicas de natureza alguma. Não há ali a menor prática dos preceitos scientificos em bem do conforto e do encaminhamento de cura, assim como falta segurança em diversos compartimentos destinados a loucos furiosos. Nem se pode, apezar de todos os esforços d'esta Superintendencia e do espírito caridoso da população, fazer coisa melhor. O problema de assistência aos loucos tem de ser resolvido no Estado por forma muito diferente. É indispensável a creação de um hospício obedecendo as regras da sciencia, bastante vasto para recolher o grande número de alienados que existe em quase todos os municípios (Joinville, 1917). 
Em resposta às vozes que emergiam a denunciar a condição desfavorável dos que eram confinados como loucos em espaços insalubres, produziramse discursos sobre a necessidade de criação de uma instituição que conferisse tratamento àquelas pessoas, criando-se o Abrigo Municipal de Alienados (1923). O terreno cedido pela Prefeitura a esse fim: os fundos do Cemitério Municipal.

Assim se deu, em Joinville, o início do convívio entre loucura e morte, que inaugura uma contradição-chave: no mesmo território em que uns são lembrados, mesmo mortos, outros (vivos) se querem esquecidos. O cemitério, distante para não causar problemas aos cidadãos, não é questionado quanto ao fato de estar próximo a certos vivos, os "loucos", aqueles que não se querem que sejam lembrados.

Entre os registros fotográficos do Abrigo de Alienados, temos, na figura 1, a imagem geral do Abrigo de Alienados, que permite observar seu afastamento da vida urbana. Essa foi a destinação que se deu na demarcação dos territórios da urbe, uma oposição entre espaços sacralizados à habitação, aquilo que se vê como belo, ou digno de ser mostrado, por um lado, e, por outro, o local de encarceramento e clausura dos infames.

Figura 1 - Registro fotográfico do Abrigo de Alienados

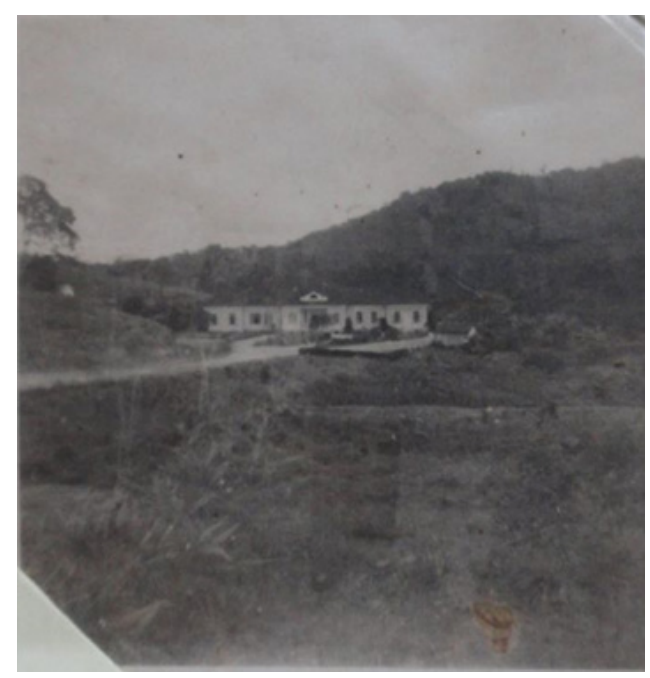

Fonte: Acervo do Arquivo Histórico de Joinville.

Essa imagem nos aproxima da realidade de uma cidade que criava seus próprios mortos-vivos. Pela fotografia, podemos ler as intenções políticas da época, os ideais de urbanização que correspondiam a certos modos de governar. 
Esse discursos esses produzidos no tensionamento entre as diferentes vozes que tramaram essa história, inclusive as que se quiseram fazer menores.

A relação dos citadinos com a morte e as medidas políticas que vinham sendo tomadas para orquestrar a civilização da pólis contextualizam a escolha da criação do espaço oficial do louco no Município. Os que se queriam longe dos vivos não eram somente os mortos de carne e osso, mas também aqueles que aos ideais civilizatórios e de urbanização faziam-se inúteis, corpos sem função no imaginário social e inadequados para a lógica da produção e do consumo.

Durante seu funcionamento, o Abrigo de Alienados recebeu homens, mulheres e crianças (menores de 15 anos) encaminhados de várias cidades do Estado. Antes, porém, de completar 20 anos de existência, em 1942, a instituição teve suas atividades encerradas, e os pacientes que se encontravam internados foram transferidos para a Colônia Santana ${ }^{6}$, nos arredores de Florianópolis.

Nessa época, o País vivia as influências da Segunda Guerra Mundial, que, entre outras medidas, fizeram com que se criassem campos de concentração ${ }^{7}$ a prisioneiros políticos. Juntamente com outro campo existente em Florianópolis, o prédio onde se instalava o Abrigo de Alienados destinou-se, no ano de fechamento dessa instituição, a servir como presídio político do Estado de Santa Catarina (Fáveri, 2009).

De acordo com Fáveri (2009), tais campos de concentração, como o que funcionou em Joinville, serviram durante os anos em que o Brasil esteve em guerra declarada aos países do Eixo (Itália, Alemanha, Japão), entre agosto de 1942 e maio de 1945, como espaço para deter aqueles que se opunham às repressões. Essas instituições,

Criadas através de leis e decretos, legitimaram a linha dura na perseguição de todo e qualquer estrangeiro, brasileiro naturalizado ou nascido no país que não se alinhasse à política ideológica de um Estado que geria a população nos mínimos detalhes, querendo homogeneizar condutas e sentidos, "abrasileirando-as" a qualquer custo (Fáveri, 2009, p. 92).

Com base em Foucault (2007), temos que a prática de internação do "louco" (assim como dos "leprosos") muito se aproxima da prática penitenciária, a partir do século XIX, pois todas respondem à necessidade de afastar certos sujeitos do

\footnotetext{
${ }^{6}$ Para mais informações sobre essa instituição, ver Borges (2013).

${ }^{7}$ A expressão "campos de concentração" é utilizada por Perazzo (2009) em seu estudo sobre os prisioneiros de guerra no Brasil, na época da Segunda Guerra Mundial. A autora justifica a escolha por tal termo para designar os presídios políticos por entender, baseada em Hannah Arendt, que a ele correspondem todos os casos de afastamento dos indesejáveis sociais, por meio da prática de concentração e confinamento, que, inclusive, existiam antes mesmo dos campos de extermínio nazista, situação histórica que levou tal prática ao extremo.
} 
meio social. Tais espaços de "internamento", para Foucault (2007), respondiam ao "mito da felicidade social", ou seja, simbolizavam a "edificação de uma cidade perfeita" via isolamento dos indesejáveis sociais. A destinação desse espaço, na ocasião de fechamento do Abrigo de Alienados, a servir como presídio político, novamente afirma, assim, a representação desse território na cidade.

Por último, tem-se a informação, com base em uma notícia veiculada no Jornal de Joinville, no início do ano de 1968, intitulada Flagrantes do dia (1968), que o prédio em condições precárias abrigava dez famílias de militares da PM do Estado que prestavam serviço em Joinville. A reportagem nos aproxima da realidade do prédio em sua última função:

Essas famílias pobres e humildes dos militares vivem em cubículos infectos e insalubres, correndo o risco de uma epidemia provocada pelas péssimas condições de higiene. Em alguns dos cubículos, transformados em quarto de dormir, vêem-se assoalhos esburacados e podres, e enquanto as crianças dormem à noite, os ratos vadeam pelos cômodos e dormitórios. Não dispondo de um sistema de esgoto, os quintais apresentam um aspecto repugnante, nocivo à saúde daqueles que ali residem. O drama vivido pelas famílias dos militares da PM deve ser encarado com seriedade e com mais humanidade (Flagrantes do dia, 1968).

Atualmente, desse prédio não restam evidências materiais, suas paredes foram demolidas, e o terreno onde ele se localizava foi tomado pelos jazigos do cemitério municipal, ilustrando talvez o fim que a essa história quis se dar: o enterro de sua existência, transformando-a em uma "memória subterrânea"8 no contemporâneo da cidade.

\section{TRANSITAR PELO CEMITÉRIO: A EXPERIÊNCIA DA PESQUISA}

A procura inicial, no setor administrativo do cemitério, por registros documentais sobre a existência do prédio levou a constatação da inexistência de qualquer tipo de material de registro e também o desconhecimento por parte de alguns funcionários sobre tal fato que compõe a história do território. O lugar para memorar os mortos e revisitar as histórias que junto aos túmulos foram enterradas parecia não estar acostumado a receber aqueles que procuravam pelos vestígios de memórias que compuseram no passado a história da "cidade dos mortos".

\footnotetext{
${ }^{8}$ Conceito de Pollak (1989) para se referir ao tipo de memória que não se escolheu preservar devido, frequentemente, a conflitos entre grupos minoritários e a sociedade englobante.
} 
O transitar da pesquisadora entre os túmulos que se encontram no local onde teria existido o prédio demolido marcava a experiência de entrar em contato com a ausência de um passado. Como um flâneur que passeia pelos lugares onde podem ser encontrados os vestígios do passado (Abreu, 2012), estar nesse território significava despertar as possibilidades de sentir as vidas e os acontecimentos enredados na trama desse passado, lançando o corpo de pesquisadora a "perambular" no cemitério de maneira nunca antes pensada.

Não existindo vestígios materiais, o olhar que se dirigia ao território aparentemente vazio ou silenciado tecia outras relações. A ausência da arquitetura (como se vê na figura 2) que poderia remeter-nos diretamente ao passado sensibilizava para a existência de algo que permanecia não dito sobre o território. Era como se pudesse experimentar, no local, a aura ${ }^{9}$ de uma paisagem que ainda resistia nesse contexto.

Figura 2 - Paisagem pretérita e atual do terreno do cemitério
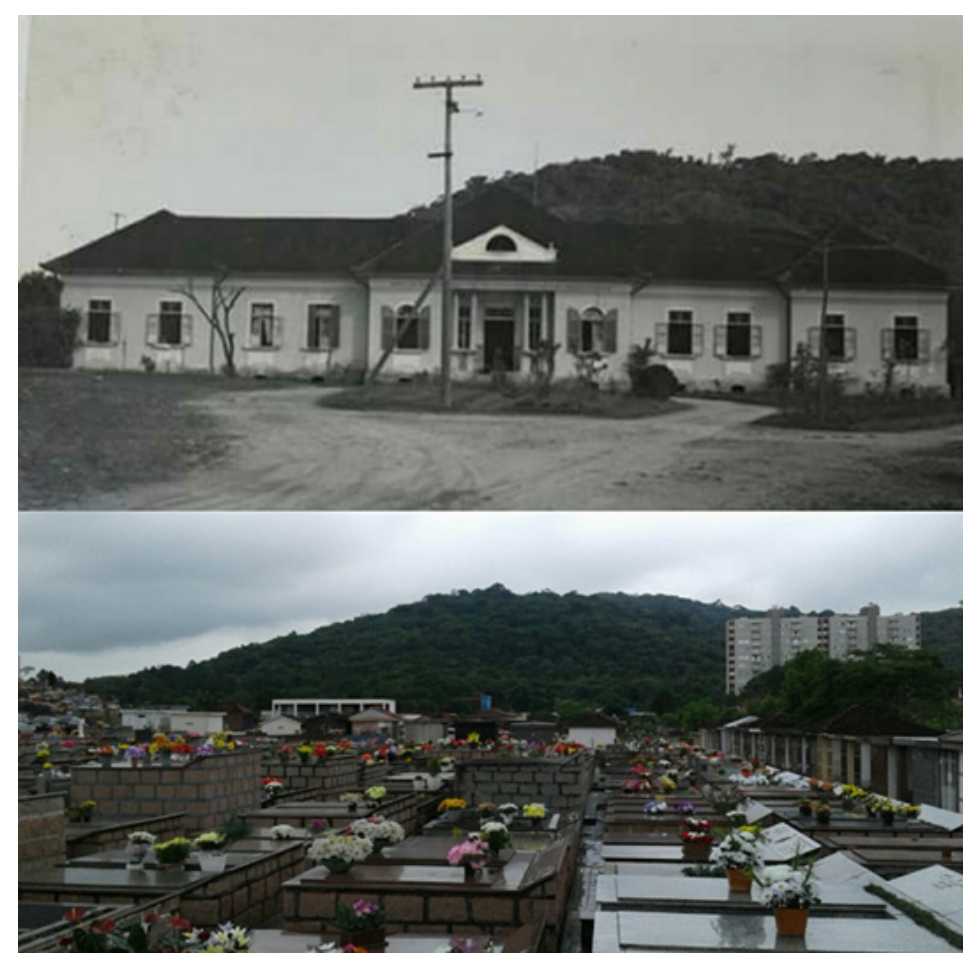

Fonte: 1 a foto - Arquivo Histórico de Joinville; 2 a foto - registro da pesquisadora.

\footnotetext{
${ }^{9}$ Aqui se fala da experiência de aura proposta por Benjamin (2012). Para ele, aura seria "Figura singular, composta de elementos espaciais e temporais, aparição única de uma coisa distante, por mais perto que esteja” (p. 440).
} 
Essa situação ilustrava a forma como os encontros entre gerações tem por costume guiarem-se do presente ao passado, a partir das "paisagens materializadas" (Assmann, 2011), ou seja, a partir do "contato direto" com uma época passada quando ainda resistem provas concretas de sua existência ${ }^{10}$. Ao dotarmos um local de aura, no entanto, podemos perceber sensorialmente o afastamento de um passado irrecuperável, onde se entretece presença e ausência; o presente sensorial e o passado histórico. A dimensão da aura atribuída a um lugar reside justamente na sua estranheza (Assmann, 2011).

Como um espectro a ressurgir no terreno do cemitério (um "hospíciofantasma"), imaginemos esse território como uma verdadeira "cidade dos mortos", local onde é possível (para aqueles que se debruçam, de forma sensível, sobre essa história) notar a existência de vozes que revelam uma heterogeneidade de tempos a compor o cenário de um cemitério, à primeira vista, silencioso.

É possível pensar que aquilo que permanece silenciado na história desse território diz respeito ao que o configura como um verdadeiro espaço de "cemitériosocial" da cidade; ao escavar as camadas dos tempos que ali concomitantemente se apresentam, os vestígios encontrados revelam a proximidade entre "morte" e "infâmia" presente em todos os destinos que a esse terreno se quis dar.

Do cemitério pulsam vestígios de memórias de uma época em que a produção da infâmia se alocou no terreno da cidade. Em comum entre os habitantes confinados nesse lugar está a experiência de resistir ao cerceamento de sua autonomia, sua posição no mundo, sua própria voz. Vozes abafadas não somente pela eternidade da morte, mas antes, porque, em vida, experimentaram a condição da clausura humana; habitam, desde então, a névoa que paira sobre essa história.

A sucessiva destinação desse espaço para abrigar a infâmia e também a morte soa como uma verdadeira "ficção", cuja trama segue um roteiro destinado a ilustrar as condiçôes mais "mortificantes" que podem experimentar em vida os humanos. Ficção, cujo enredo causa estranhamento aos seus ouvintes (transeuntes desse espaço que desconhecem ou pouco se lembram dessa história), pode ser recontada a partir de uma relação outra que com ela se estabeleça, relação ética e sensível para com um passado de memórias difíceis.

O cemitério passava a ganhar ares de um campo ficcional, onde se podia criar sentidos vários ao deixar-se afetar pela presença incômoda de um aparente silêncio de morte. Como no conto Bobók, de Dostoievski (Bezerra, 2012), que

${ }^{10}$ Essa é a chamada "lógica da força vinculativa dos lugares com o passado", discutida por Assmann (2011). 
faz do cemitério cenário de uma ficção em que o personagem principal ausculta as vozes dos mortos dentro dos túmulos a balbuciar seus últimos restos de vidas, é possível aproximar-se do contexto da morte para dele produzir tensões: ao criar paradoxos do limiar entre vida e morte, abrem-se frestas para produzir fala daquilo que, silenciado, "descansa em paz".

Se as vozes da cidade dos mortos, assim como no conto de Dostoievski, pudessem ser escutadas por um dia, provavelmente teriam segredos a contar. Restos de vidas pulsam entre os túmulos e ecoam no território dos mortos; para ouvi-los, é preciso enredar-se na ficção, fazer do cemitério "cenário", da morte "linguagem", dos túmulos "vestígios", e dos mortos "personagens".

$(\mathrm{Re})$ criar realidades pode não ser condição utópica e distante. Entre ficção e pesquisa, existe ponto de encontro, é o que nos faz pensar Costa (2014):

Reinventando nossa realidade independente dos estados de coisas referentes, podemos torná-la ainda mais real, mais complexa, densa e intensa ao intrincar suas tramas com novas possibilidades de relação. A ficção fia mundos onde a confiança ultrapassa a fidedignidade sem perder realidade (p. 553).

Levar para o campo da ficção observações de situações cotidianas, leituras de um espaço, ou a escuta da polifonia urbana, como fez Dostoievski em suas obras, nas quais imaginário e real encontram-se sempre imbricados (Bezerra, 2012), equivale afirmar para a pesquisa possibilidades outras da construção do saber que irrompem a perspectiva do verdadeiro e falso (Costa, 2014).

Nas visitas da pesquisadora realizadas ao cemitério, algumas vezes acompanhada por funcionários do local, passou-se a entrar em contato, ora com a negação da referida história, ora com as narrativas que ainda ressoavam sobre a existência das instituições naquele local, e também sobre demais memórias que constituem o cemitério.

A "negação" sobre a existência das instituições ilustra-se em situações como a ocorrida numa das buscas no cemitério por vestígios materiais do prédio, em que um dos coveiros, sabendo do motivo do transitar da pesquisadora naquele espaço, insistia em tensionar a investigação dizendo: "Já encontrou algum hospício?”, "Não tem hospício por aqui, não!". A figura do coveiro (aquele que trabalha cotidianamente com o silêncio da morte) trazia o silenciamento sobre a história que não recebeu sua lápide.

Em contraste com o desconhecimento de algumas pessoas quanto ao objeto de estudo que se investigava, a convivência naquele espaço permitiu conhecer algumas nuances do funcionamento do cemitério, como o fato de ele ter algumas nomeaçôes informais entre aqueles que ali trabalham, que nos aproximavam dos 
vestígios de suas histórias passadas. Teve-se conhecimento, assim, da "Quadra do hospício", região do cemitério nomeada pelos coveiros mais antigos, onde ficam os túmulos que se erigiram sobre o solo que se edificou o Abrigo de Alienados.

Essa informação, a qual nem todos detêm, faz parte do cotidiano do cemitério, servindo à localização daqueles que ali trabalham. Trata-se de uma memória cristalizada na adjetivação, mas negada como possibilidade de sentido, ou seja, ela não parece afetar as experiências dessas pessoas que ali circulam (e muito menos extrapolar os muros do cemitério, participando das narrativas dos citadinos), a ponto de ser problematizada e de configurar-se como disparadora de sentidos.

Foi possível notar, então, a partir destas e de outras narrativas, que, no cemitério, também se partilham memórias e esquecimentos. Ainda que algumas pistas fossem difíceis de serem seguidas, e algumas personagens insistiam em não dar respostas, ou faziam desistir da procura pelos vestígios da história desacreditada, estar no cemitério tornava o olhar da pesquisa mais sensível aos vestígios de vidas outras que habitaram aquele lugar, bem como à possibilidade de abrir os sentidos aos seus narradores (aqueles que falam a partir de sua experiência nesse local) para investigar os vestígios do passado e apropriar-se desse espaço, reconhecendo, tal como indica Abreu (2012), configurações que não são visíveis.

Entre as pessoas que trabalham nesse lugar, embora desconhecedores do cotidiano interno das instituições da clausura, já que não tiveram acesso a ela, alguns conseguem apontar alguns vestígios da existência da referida edificação. No contato inicial que se fez com um dos funcionários mais antigos do cemitério, ele leva a pesquisadora até a região exata da existência do prédio e, em sequência, passa a desenhar em silêncio numa folha sobre uma prancheta (figura 3) a estrutura física do local, escrevendo a ordem dos destinos que a ele se deu (hospital, presídio, moradia da polícia e cemitério), e o terreno do cemitério, destacando suas transformações e reformas. 


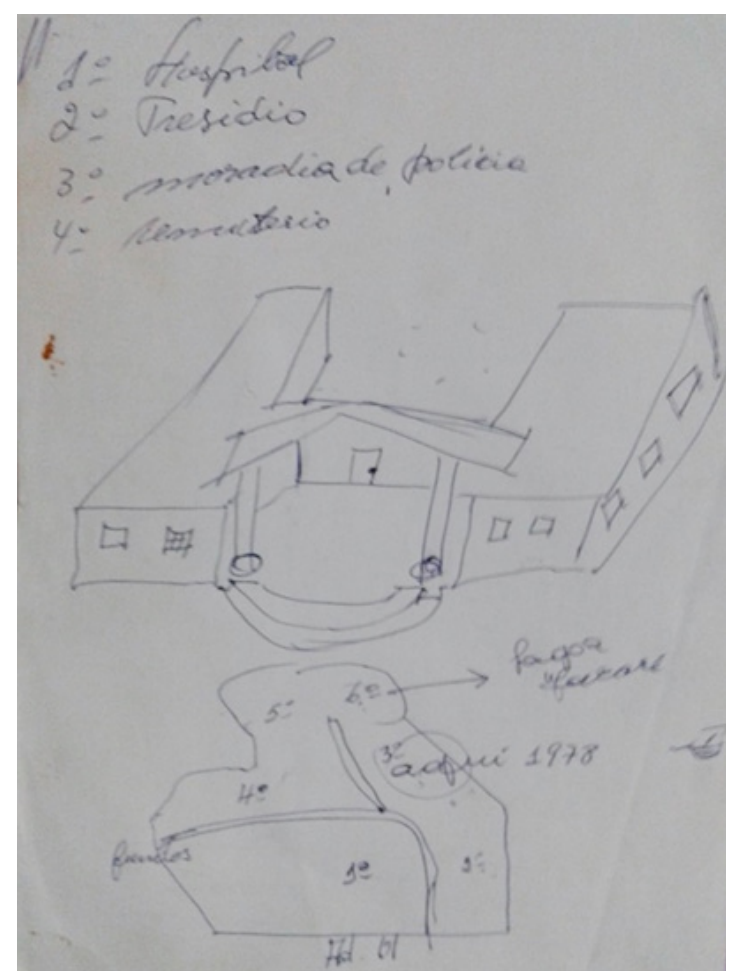

Fonte: acervo da pesquisadora.

Sua memória quanto à estrutura do prédio e as outras informações sobre o terreno do cemitério e as diferentes reformas feitas no lugar demonstram a maneira como preserva a experiência daquele território e a compartilha via narrativa da história do cemitério. Quando questionado sobre a data da demolição do prédio, guia a pesquisadora para os túmulos que estão no solo que, no passado, recebeu ambas as instituições. Ensina que eles são pistas para se aproximar da história do prédio: os anos de falecimento gravados nas lápides mostram em que época os túmulos passaram a ser construídos naquela região. A data mais antiga, que correspondia ao ano de 1977, indica que, pouco antes disso, o prédio já teria sido demolido.

Experiências como essa fazem compreender os vestígios e rastros da "cidade dos mortos" como forma de fazer ponte com o passado que marcou esse território. Podemos observar, no cenário atual do cemitério, os vestígios que marcam os vários tempos desse espaço, que reúne, nas lápides dos túmulos, registros de épocas, camadas sociais e trajetórias de vidas das mais diversas. 
O terreno do cemitério, nesse sentido, concretiza-se como cronotopo, no sentido que emprega Bakhtin (2003): uma condensação de variados tempos em um mesmo espaço e cuja leitura se concretiza como possibilidade de "compreender uma forma acabada de experiências inacabadas" (Machado, 2010, p. 209). São inacabadas, pois, em Bakhtin, tempo e espaço não existem em si mesmos, como entidades absolutas, "são transformações semióticas de vivências em sistemas culturais produtores de sentido" (Machado, 2010, p. 212).

Essa indissolubilidade entre tempo e espaço se evidencia no local de realização dessa pesquisa. Imperceptível ao olhar de quem ali transita, lemos o terreno do cemitério como o espaço geográfico onde se depositam os restos da existência das instituiçôes onde se enclausuravam vidas; num primeiro momento, aquelas que passaram pelo Abrigo de Alienados, e, em última instância, as que foram isoladas no presídio político. Nesse território, encontram-se "vestígios" da vontade humana de construção e de apagamento dessas duas instituições, o que nos permite pensar nos laços concretos que vinculam o passado à vida contemporânea da cidade.

Os habitantes do Cemitério Municipal de Joinville (todos os mortos ali sepultados) e aqueles que, pelas instituiçôes da clausura e da loucura, tiveram passagem, os mortos-vivos, são testemunhas de um passado marcado por tensões, conflitos e disputas. As vozes abafadas pela morte que ainda pairam sobre esse cenário continuam a protagonizar a trama que a esse lugar sempre se destinou, $o$ silenciamento de vidas. Vozes de diferentes tempos, camadas sociais e trajetórias de vidas, dialogando num mesmo espaço, sob o mesmo solo, a testemunhar e tensionar o (des)aparecimento do lugar da clausura humana e o silenciamento em relação às violências que ali tiveram guarida.

\section{CONSIDERAÇŌES FINAIS}

As ações de patrimonialização se tornam significativas para pesquisadores interessados em estudar a cidade, visto que permitem exemplificar as disputas entre as memórias, a seleção do que será iluminado e a produção dos apagamentos, das invisibilidades. Como nos explica Abreu (2012), "Ao selecionar um aspecto de memórias múltiplas e polissêmicas e ao concentrar os esforços para iluminar esse único aspecto, o movimento de patrimonialização seria também um movimento de apagamento" (p. 23). Nesse sentido, a ausência do prédio que não foi patrimonializado, assim como outros construídos na mesma época na cidade, nos diz que suas memórias não foram privilegiadas. 
E se a memória não se preserva sozinha, mas necessita de agentes e de suportes (Abreu, 2012), talvez as pesquisas que procurem narrar as invisibilidades, lançar luz sobre determinados sujeitos e fatos históricos obscurecidos, e dar o devido valor às narrativas que no cotidiano acelerado da cidade estão se fazendo esquecidas possam ser ações de transformação sobre o espaço urbano.

Assim se deu a intenção de perambular pela "cidade dos mortos". Ao se perder, muitas vezes, pelos caminhos de uma memória silenciada, esta pesquisa procurou apropriar-se desse espaço urbano para ali ouvir as vozes que ainda resistem ao silenciamento socialmente produzido e desacostumar o olhar transitório que se lança ao cemitério, ficcionando possibilidades de compreendê-lo ao fazer emergir novas formas de se relacionar com as várias vidas que ali de algum modo ainda vivem. 


\section{REFERÊNCIAS}

Abreu, R. (2012). Colecionando museus como ruínas: percursos e experiências de memórias no contexto de açôes patrimoniais. Ilha Revista de Antropologia, 14(1-2), 17-35. Recuperado a partir de_https://periodicos.ufsc.br/index.php/ ilha/article/view/2175-8034.2012v14n1-2p17/24005

Assmann, A. (2011). Espaços da recordação: formas e transformaçôes da memória cultural. P. Soethe (Trad.). São Paulo: Ed. Unicamp.

Bakhtin, M. (2003). O tempo e o espaço nas obras de Goethe. In P. Bezerra (Trad.), Estética da criação verbal. (5a ed., pp. 225-258). São Paulo: WMF Martins Fontes.

Benjamin, W. (2012). A obra de arte na era de sua reprodutibilidade técnica. In S. P. Rouanet (Trad.). Magia e técnica, arte e política: ensaios sobre literatura e história da cultura. (Obras escolhidas, Vol. 1, 8a ed., pp. 179-212). São Paulo: Brasiliense.

Bezerra, P. A. (2012). O universo de Bobók. In Dostoievski, F. Bobók. (pp. 3851). São Paulo: Ed. 34.

Borges, V. T. (2013). Um "depósito de gente": as marcas do sofrimento e as transformações no antigo Hospital Colônia Sant'Ana e na assistência psiquiátrica em Santa Catarina, 1970-1996. História, Ciências, Saúde, 20 (4), 1531-1549. Recuperado a partir de: http://www.scielo.br/pdf/hcsm/v20n4/0104-5970hcsm-20-04-01531.pdf

Costa, L. A. (2014). O corpo das nuvens: o uso da ficção na Psicologia Social. Fractal: Revista de Psicologia, 26 (n. esp.), 551-576. Recuperado a partir de http://www.scielo.br/pdf/fractal/v26nspe/1984-0292-fractal-26-spe-0551.pdf

Castro Filho, L. (2007). Cidade dos mortos ou lugar dos vivos? (Dissertação de Mestrado). Universidade Federal do Paraná, Programa de Pós-Graduação em Geografia, Curitiba.

Dostoiévski, F. (2012). Bobók. P. A. Bezerra (Trad.). (pp. 15-37). São Paulo: Ed. 34.

Fáveri, M. (2009). Tempos de intolerância: repressão aos estrangeiros. Revista Esboços, 16(22), 91-109. Recuperado a partir de https://periodicos.ufsc.br/ index.php/esbocos/article/view/2175-7976.2009v16n22p91/16326 
Flagrantes do dia. (1968, 13 janeiro). Jornal de Joinville. Joinville: Arquivo Histórico de Joinville.

Fochi, G. (2011). Morte, cemitérios e jazigos: um estudo do Cemitério Municipal de Joinville/SC. (Dissertação de Mestrado). Universidade da Região de Joinville, Joinville.

Fontoura, A. (2005). Aqui “jaz” um hospital. In: S. P. L. C. Guedes (Org), Histórias de (i)migrantes: o cotidiano de uma cidade. (pp. 77-103). Joinville: Editora Univille.

Foucault, M. (2003). Microfisica do poder (18a ed.). R. Machado (Trad.). Rio de Janeiro: Graal.

Foucault, M. (2007). História da loucura na Idade Clássica. J. T. Coelho Netto (Trad.). São Paulo: Perspectiva.

Gagnebin, J. M. (2006). Lembrar, escrever, esquecer. São Paulo: Ed. 34.

Guedes, S. P. L. C. (1996). Instituição e sociedade: a trajetória do Hospital Municipal São José de Joinville: 1852-1971. Joinville: Movimento \& Arte.

Guedes, S. P. L. C. (2005). A Colônia Dona Francisca: a vida... o medo... a morte. In S. P. L. C. Guedes (Org.), Histórias de (i)migrantes: o cotidiano de uma cidade. (2a ed., pp. 11-48). Joinville: Editora Univille.

Hissa, C. E. V. \& Melo, A. F. (2008). O lugar e a cidade; conceitos do mundo contemporâneo. In: C. E. V. Hissa (Org.), Saberes ambientais: desafios para o conhecimento disciplinar. (pp. 293-308). Belo Horizonte: Ed. UFMG.

Hissa, C. E. V. \& Nogueira, M. L. M. (2013). Cidade-corpo. Revista UFMG, 20(1), 54-77. Recuperado a partir de https://www.ufmg.br/revistaufmg/ downloads/20/3-cidade-corpo_cassio_hissa_e_maria_nogueira.pdf

Joinville. (1898). Resoluçôes do Conselho Municipal de Joinville do ano de 1898, sessão de Regulamento, Capitulo II, artigo 28. Joinville: Arquivo Histórico de Joinville, 1898.

Joinville. (1906). Relatório da Superintendência do ano de 1906, redigido pelo superintendente Procópio Gomes. Joinville: Arquivo Histórico de Joinville.

Joinville. (1917). Relatório publicado na Gazeta do Comércio de 03/03/1917. Joinville: Arquivo Histórico de Joinville. 
Machado, I. (2010). A questão espaço-temporal em Bakhtin: cronotopia e exotopia. In L. de Paula \& G. Stafuzza (Orgs.), Círculo de Bakhtin: teoria inclassificável. (pp. 203-234). Campinas: Mercado das Letras.

Perazzo, P. F. (2009). Prisioneiros da Guerra: os "súditos do Eixo" nos campos de concentração brasileiros (1942-1945). São Paulo: Associação Editorial Humanitas, Imprensa Oficial do Estado de São Paulo.

Pollak, M. (1989). Memória, esquecimento, silêncio. D. R. Flaksman (tad.). Estudos Históricos, 2(3), 3-15. Recuperado a partir de http://bibliotecadigital. fgv.br/ojs/index.php/reh/article/view/2278

Santos, M. (2006). A natureza do espaço, técnica e tempo: razão e emoção. São Paulo: Hucitec.

Silva, J. A. F. (2000). Tratado de direito funerário. São Paulo: Método. 